\title{
Possibility of Harnessing Social Capital to Support the Development of Payment for Environmental Services in Small-Scale Forests: A Case of Jatigede Catchment Area
}

\author{
Nunung Parlinah ${ }^{1^{*}}$, Bramasto Nugroho $^{2}$, Muhamad Buce Saleh $^{2}$, Hendrayanto $^{2}$ \\ ${ }^{1 *}$ Graduate School of Bogor Agricultural University, Dramaga Main Road, Campus IPB Dramaga, Bogor, Indonesia 16680 \\ ${ }^{2}$ Department of Forest Management, Faculty of Forestry, Bogor Agricultural University, Academic Ring Road, Campus IPB \\ Dramaga, PO Box 168, Bogor, Indonesia 16680
}

Received February 21, 2018/Accepted May 25, 2018

\begin{abstract}
The concept of social capital has gained attention as a source of support in implementing Payment for Environmental Services (PES). Environmental services, in the context of better water yields in watersheds, is affected by good land cover conditions of forests including small-scale private owned forests. Although some research results indicate that private owned forests are more economic oriented than environmental functions, but its existing social capital can be harnessed to implement PES in small-scale forests. The aim of this study was to analyze the potential of social capital as a source of support in the implementation of PES. The research was conducted by survey method. This research revealeds that the level of trust in local community leaders is very high. This role models can be an key entry point for realizing the PES scheme by strengthening the common knowledge of environmental benefits of small-scale forests and strengthen community norms related to the protection of water resources. Leadership and networking capabilities of the community institution leader give a real influence in collaboration between groups.
\end{abstract}

Keywords: small scale forests, payment for environmental services, social capital, community institution

*Correspondence author, email: nparlinah@forda-mof.org, tel.: +62-251-8633234,fax.+62-251-8638111

\section{Introduction}

Payments for Environmental Services (PES) programs in various countries have been implemented to provide financial incentives for conservation of forest and reduction of deforestation (Kosoy et al. 2007; Engel et al. 2008; Muradian et al. 2010). PES is defined as a voluntary transaction between service users and service providers depend on agreed rules on natural resource management to produce services (Wunder 2015). The transfer of resources between social actors aims to create incentives to harmonize individual and/or collective land use decisions with social interests in natural resource management (Muradian et al. 2010). The Regional Forum on Payment Schemes for Environmental Services in Watersheds (2004) defines PES as a compensation payment of environmental services to service providers by users of environmental services. PES schemes in watersheds are the implementation of market mechanisms to compensate for upland landowners to maintain or modify certain land uses, which affect the availability and/or quality of water resources downstream. The existence of forest has benefited to arrange the water system, sedimentation process, and the water flow during the dry season (Junaidi \& Tarigan 2011). There is a significant relationship between land use and water quality parameters.
The more forested a watershed is, the less sediment and nutrients load to the stream (Kibena et al. 2014).

Small scale private owned forests are part of land use in the catchment area. The existence of small scale forests provide economic benefits to the owners and provide environmental benefits to other parties. The economic benefits contribute to farmer income (Hardjanto 2001; Darusman \& Hardjanto 2006), while environmental benefits, e.g., maintaining the water source discharge (Widarti 2015) benefited by the wider community. Main motivation of the smallholder in developing the forests, especially in Java Island, is economic reasons (Lastini 2012; Nugroho \& Tiryana 2013).

In order to assure that the environmental benefits of small scale forests can be benefited on a wider scale, it requires policy interventions through PES mechanisms. PES is an approach to resolve externalities in achieving environmental and conservation goals (Ajayi et al. 2012). PES also internalizes the positive externalities of uncompensated environmental services (Kerr et al. 2007). This approach is included in an economic incentive-based arrangement (Yin et al. 2013); a policy designed to influence or motivates individuals and communities to perform certain actions (Emerton 1999). 
Implementation of PES mechanisms requires collaboration and collective action including from forest owner. Linking environmental service schemes into local (rural) institutions can promote equitable outcomes, primarily through collective action to lower transaction costs and reduce the barriers to smallholder participation (Beckmann \& Padmanabhan 2009). Voluntary collaboration among the people will be easier if the people already have social capital (Putnam et al. 1993). According to Liu et al. (2014), high level of social capital, particularly the cognitive variant, is instrumental in encouraging residents' pro environmental behaviors. Social capital is also important for crafting and implementing PES schemes that ensure the provision of environmental services and distribute benefits fairly within the communities (Rosa et al. 2004). Mauthe et al. (2015) states that social capital can in turn directly affect natural capital by facilitating collective action and effective ecosystem management. Social capital refers to the features of social organizations such as trusts, norms, and networks (Putnam et al. 1993). It is not just meant as cohesiveness of social relations within an institution or community group, but it is also viewed more broadly as something that makes societies aligned and united in order to achieve common goals (Fukuyama 2007). Social capital and its components have become social glue that will keep the unity of group members (Djohan 2008). Farmer group, as community institutions, is one reflection of collective action in the community. Community action has a correlation with bonding and bridging social capital (Agnitsch et al. 2006). As an example, the farmers' groups are able to facilitate collective actions in implementation of activities related to agriculture, forestry, and livestock.

Putnam (2000) distinguish between bonding and bridging social capital. Bonding social capital refers to trust and strong ties within homogenous groups, whereas bridging social capital refers to diverse network and link between groups. Linking social capital refers to the link between individuals and groups in hierarchical relationships (Woolcock 2001). The purpose of the research is to analyze the potential of social capital in the form of trust, norm, and

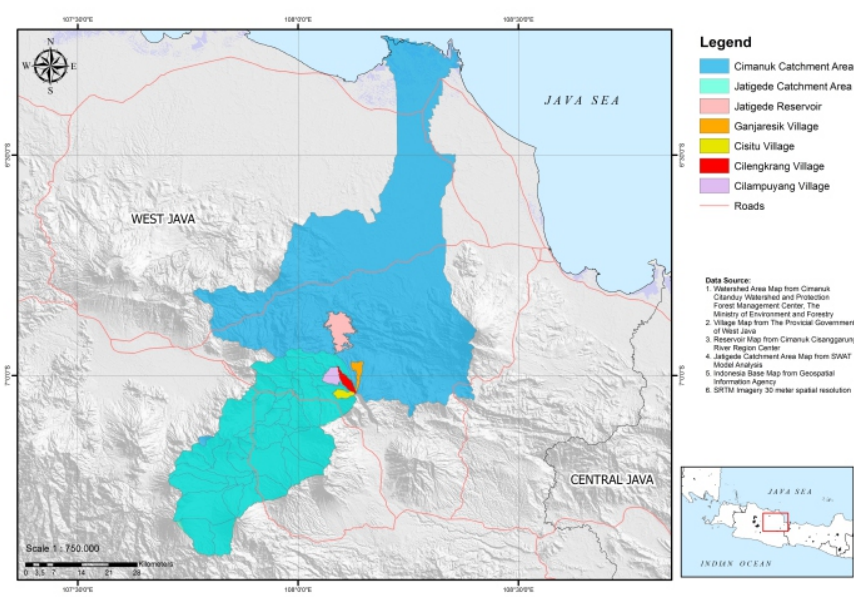

Figure 1 Research location on four villages of Jatigede. network and community engagement as a source of support in the development of PES (Putnam et al. 1993; Acquaah et al. 2014)

\begin{abstract}
Methods
Location and time The research was conducted in four (4) villages located in Jatigede catchment area, part of Cimanuk Watershed (Figure 1). Cimanuk Watershed is located in the region of four regencies i.e. Garut, Sumedang, Majalengka and Indramayu, West Java Province. The villages were taken from several sub basins resulting from Soil and Water Assessment Tool program which is closest to Jatigede Reservoir. Field data collection was conducted from June 2016 until January 2017.
\end{abstract}

Data collection This study used survey method involving questionnaires. The respondent unit was smallholder household. As many as 135 respondents were selected purposively ( $3 \%$ of the households, from 4 sample villages). In order to assess more detailed information regarding small scale forests management and community institution, indepth interviews with several informants were also conducted. Data on distribution and population density of the villages were derived from Sumedang Central Bureau of Statistics (2016) and Garut's Central Bureau of Statistic (2016). Data of small-scale forests in each village were analyzed based on the 2015s' land cover maps obtained from the Ministry of Environment and Forestry.

Data analysis Social capital concept from Putnam (1993) was used as basic theoretical framework in the reserch. Social capital variables measured were trust, norms, and networking (Putnam et al. 1993) including civic engagement (Acquaah et al. 2014). The analysis was implemented by comparing the score (based on the Likert scale) of social capital variables. Classification of the score was undertaken by using hose value formula (Supranto 2000). The number of classes are divided into three classes (low, medium, and high) which is adjusted to the desired level of categories.

Statistical analysis of social capital variables (trust, norms, networking) was used in this study non-parametric Kruskal-Wallis test to determine whether there is a significant difference for each variable of social capital. Multiple pairwise comparisons using Dunn test were used in the next step to know the difference of social capital variable between villages. To assess the effectiveness of social capital in encouraging collective action to develop PES by utilizing existing community institutions, eight principles of the effective institutional design according to Ostrom (1990) was emloyed. The principles are clearly defined boundaries, congruence between appropriation and provision rules and local condition, collective choice arrangements, monitoring, graduated sanction, conflict resolution mechanisms, minimal recognition of rights to organize, and nested enterprises.

\section{Results and Discussion}

Small-scale private forests in research site The water catchment area of Jatigede Dam (based on the SWAT program delineation at the outlet point of Cimanuk-Wado 
Water Station $\left(\mathrm{S}^{\circ} 57\right.$ and $\left.\mathrm{E} 108^{\circ} 05^{\prime}\right)$ ) is 127674 ha. Tenurial status of the land in the location is mostly dominated by private land (73.3\%), and the rest is state forest area. In 2003, total area of small scale private forests (forest land owned privately by farmer, usually an area less then 1 ha with a separate location) contributed $21.5 \%$ to the type of land use on private land. Total area of small scale forests declined in 2012 and 2015 to become $20.9 \%$ and $9.2 \%$ respectively (Table 1). The dynamics of land cover on small scale forests (together with other land cover) have had an effect on the hydrological function of annual water yield as monitored at the Cimanuk-Wado Water Station (Table 1).

Based on analysis of land cover maps of 2015 from the Ministry of Environment and Forestry (overlaid with an administrative map), the potential of small scale forests in Cilengkrang, Ganjaresik, Cisitu, and Cilampuyang villages have a high potential and relatively stable during 2003 to 2015 (Table 2). The village with the highest forest area in 2015 was Cilengkrang which was 444.08 ha. While the least was Ganjaresik with 40.63 ha. Comparing with the area of small scale forest between 2003 and 2015, the forests in Ganjaresik and Cilampuyang villages were stable. On the other side, the forest decresed by $7.97 \%$ (38.48 ha) in Cilengkrang Village and increased by $15.20 \%$ (48.73 ha) in Cisitu Village.
Planting pattern applied by the smallholder in the research location is dominated by forest tree stands and combination between timber and agriculture crops or known as agroforestry system. Most selected types of wood plants are fast growing species such as sengon (Paraserianthes falcataria), gmelina (Gmelina arborea Roxb), acacia (Acacia sp.), and jabon (Anthocephalus sp.). For slow growing species, mahogany (Swietenia sp.) is the most preferred species. On the average, timber harvesting for fast growing species is five years, although some farmers harvest their trees when the plants is stillyoung (less than five years old) or more due to financial necessity. For slow growing species such as mahogany, the farmers generally cut down the trees when the plants are 15 years old or even older. The location of forest tree stands is found generally on Cimanuk riverbanks and on areas with high slope. The description of the condition of small scale forests in the research site is presented in Figure 2.

Population density in all four villages was categorized as medium (251-400 people $\left.\mathrm{km}^{-2}\right)$ to very high ( $>401$ people $\mathrm{km}^{-2}$ ) (Table 3). The majority of the population worked as farmers. As described earlier, cropping pattern commonly found in the research area was forest tree stands and agroforestry. However, there was also area managed for paddy fields and agricultural crops cultivation. The

Table 1 The effect of land use change on hydrological

\begin{tabular}{lrrrr}
\hline \multirow{2}{*}{ Land status/discharge } & \multicolumn{4}{c}{ Year } \\
\cline { 2 - 5 } & \multicolumn{1}{c}{2003} & \multicolumn{1}{c}{2012} & \multicolumn{1}{c}{2015} \\
\hline State forests (ha) & $34,077.71$ & $34,077.71$ & $34,077.71$ & $34,077.71$ \\
Non-state forests (ha) & $93,596.29$ & $93,596.29$ & $93,596.29$ & $93,596.29$ \\
$\quad$ Small scale private forests & $20,148.09$ & $20,563.38$ & $19,649.43$ & $8,580.42$ \\
Estate crop & 370.94 & 397.47 & 397.47 & 214.41 \\
Settlement areas & $8,704.52$ & $8,728.22$ & $8,728.22$ & $8,768.49$ \\
Dry agricultural land & $34,273.45$ & $34,755.19$ & $35,669.14$ & $50,819.43$ \\
Paddy field & $29,917.32$ & $28,970.84$ & $28,970.84$ & $25,075.62$ \\
Non-forest dry shrub & 44.11 & 44.11 & 44.11 & - \\
Bare ground & 129.69 & 128.90 & 128.90 & 129.76 \\
\hline Open water & 8.16 & 8.16 & 8.16 & 8.16 \\
\hline Sum (ha) & $127,674.00$ & $127,674.00$ & $127,674.00$ & $127,674.00$ \\
\hline Debit (m ${ }^{3}$ yr $^{-1}$ ) & $775,054,656$ & $870,589,728$ & $1,181,632,320$ & \\
\hline
\end{tabular}

Table 2 Distribution of small-scale private forests in research site

\begin{tabular}{|c|c|c|c|c|}
\hline \multirow{2}{*}{ Regency } & \multirow{2}{*}{ Sub District } & \multirow{2}{*}{ Villages } & \multicolumn{2}{|c|}{ Small-scale forests area (ha) in year } \\
\hline & & & 2003 & 2015 \\
\hline \multirow[t]{2}{*}{ Sumedang } & Wado & Cilengkrang & 482.56 & 444.08 \\
\hline & & Ganjaresik & 40.63 & 40.63 \\
\hline \multirow[t]{2}{*}{ Garut } & Malangbong & Cisitu & 320.61 & 369.34 \\
\hline & & Cilampuyang & 212.06 & 212.06 \\
\hline
\end{tabular}




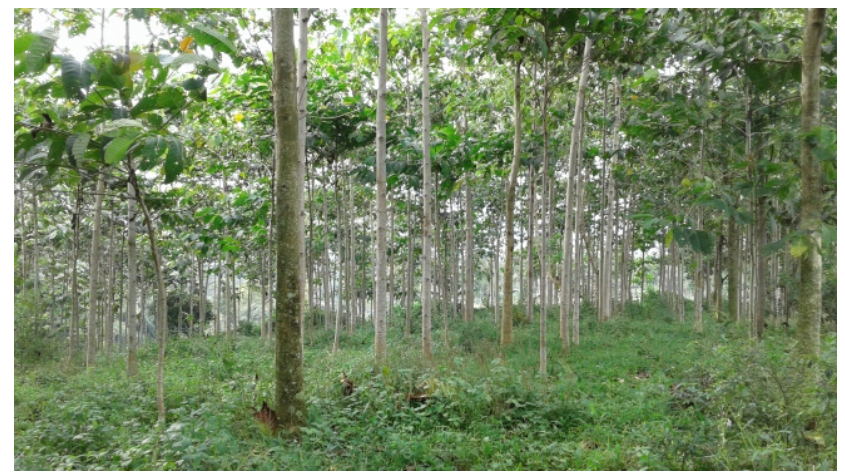

(a)

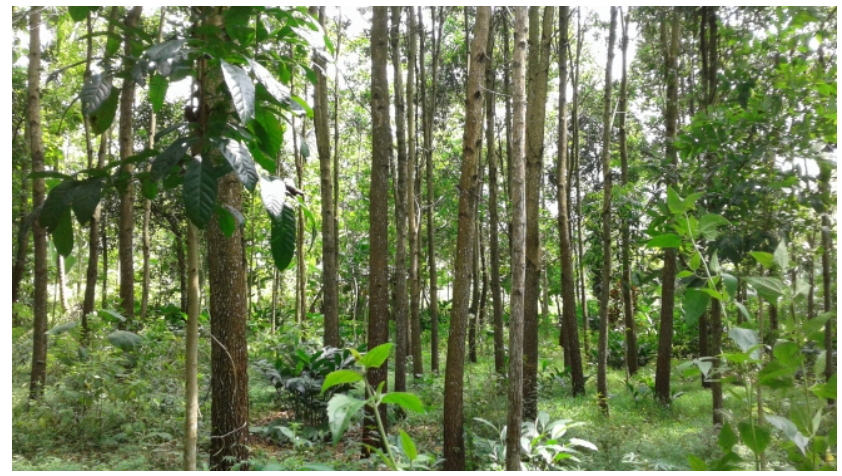

(b)

Figure 2 Small-scale private forests in research site. Cilengkrang community forest (a), Cilampuyang community forest (b).

Table 3 Population density of villages in research site

\begin{tabular}{lccc}
\hline Villages & $\begin{array}{c}\text { Total area } \\
\left(\mathrm{km}^{2}\right)\end{array}$ & $\begin{array}{c}\text { Total } \\
\text { population }\end{array}$ & $\begin{array}{c}\text { Population } \\
\text { density }\end{array}$ \\
\hline Cilengkrang & 16.62 & 5,470 & 329 \\
\hline Ganjaresik & 9.88 & 3,831 & 388 \\
Cisitu & 3.93 & 5,674 & 1,443 \\
Cilampuyang & 14.70 & 5,027 & 342 \\
\hline
\end{tabular}

frequency of rice harvest was generally 2-3 times per year, while the harvest of agricultural crops depends on the planted species. The agriculture crops planting pattern was generally a mixture of various types of crops such as corn, peanuts, ginger, and cassava.

Social capital performance Most of the people in Cilengkrang, Ganjaresik, Cisitu, and Cilampuyang villages were Sundanese. Residents coming from other areas or other tribes such as Java, Betawi, and Minang can adapt to local customs and norms so that they can be get along well with the local community. Social capital variables i.e. trust, norm, and networking can be seen in everyday life. The analysis of social capital variables indicated that trust and norm in all four villages was high. For networking variable, Ganjaresik Village had medium value, while the other three villages had high value (Table 4). The aggregate value indicates that all four Villages had high social capital. Ganjaresik village has the lowest social capital value compared to other villages, and Cisitu Village had the highest value of social capital.

Trust The attitude of mutual trust, strong belief in local leaders (religious leaders), and mutual cooperation in various activities are a reflection of trust value in the community (disscussing about participation and its relation to social capital and collective action). Participation in activities is not only in the form of labor such as participating in the construction of houses or improving public facilities (such as roads and irrigation channels), but also in the form of donations of objects such as wood to build a worship place and school.
Analysis on trust variable by using Kruskal-Wallis nonparametric test shows that there was no significant difference among the four villages (Table 5). This can be seen from the value of $p$-value $(0.0661)$ which is greater than $\alpha=$ 0.05 (95\% significance level). Indicators used to assess the variable of trust are trust to other people from similar ethnic group, from different ethnic group, outsiders, local leader, local government (village), government, partner institutions, trust maintain social glue and to cooperate in forest management. There is one indicator that respondents in the four villages give the same value (high) of trusting their local leader. Religious leaders and elderly figures are those who are considered local leaders by the community.

Further analysis using Dunn test (Table 6) shows that there was a significant difference value of trust between Cilampuyang and Cisitu villages. The substantial difference in value of trust in Cilampuyang Village comes from lower trust indicators where people tend to be more cautious about people from different ethnic and people from outside the region. This indicates that bridging social capital of Cilampuyang Village is lower than Cisitu society. This is logical when looking at tribe diversity living in Cilampuyang Village. Result from interviews with respondents reveals that there were only two tribes in Cilampuyang Village i.e. Sundanese and Javanese. Whereas in the other three villages, the population is more diverse. Villagers of Cilengkrang come from various tribes i.e. Sunda (majority), Java, Minang, and Betawi. Cilengkrang village is also residence for those who are affected by Jatigede Dam construction. Likewise, for Cisitu Village, people come from different tribes i.e. Sundanese (majority), Javanese, Betawi, Minang and Minahasa. Religion, in this case Islam becomes an important factor in the level of community acceptance in Cisitu Village. Different situation occurs in Ganjaresik Village, although there were only two tribes (Sundanese and Javanese), religion adherents in the village were Moslem and Christians. Whereas in the other villages, the majority of its population was Moslem.

Norms The norms variable of social capital were tested based on seven indicators, namely the level of understanding 
Table 4 Analysis of social capital element of respondents in research site

\begin{tabular}{|c|c|c|c|c|c|c|c|}
\hline \multirow{2}{*}{$\begin{array}{l}\text { Criteria for social } \\
\text { capita }\end{array}$} & \multicolumn{3}{|c|}{ Level of score } & \multirow[t]{2}{*}{$\begin{array}{l}\text { Cilengkrang } \\
(\mathrm{N}=36)\end{array}$} & \multirow[t]{2}{*}{$\begin{array}{l}\text { Ganjaresik } \\
(\mathrm{N}=35)\end{array}$} & \multirow[t]{2}{*}{$\begin{array}{l}\text { Cisitu } \\
(\mathrm{N}=31)\end{array}$} & \multirow[t]{2}{*}{$\begin{array}{l}\text { Cilampuyang } \\
(\mathrm{N}=33)\end{array}$} \\
\hline & Low & Medium & High & & & & \\
\hline Trust & $<16.7$ & $\geq 16.7$ to $<23.4$ & $\geq 23.4$ & 27.97 & 27.66 & 28.35 & 27.33 \\
\hline Norms & $<11.6$ & $\geq 11.6$ to $<16.2$ & $\geq 16.2$ & 20.19 & 18.89 & 20.32 & 19.00 \\
\hline Networking & $<18.3$ & $\geq 18.3$ to $<25.6$ & $\geq 25.6$ & 26.61 & 25.46 & 28.16 & 30.18 \\
\hline Total & $<46.7$ & $\geq 46.7$ to $<65.4$ & $\geq 65.4$ & 74.78 & 72.00 & 76.84 & 76.52 \\
\hline
\end{tabular}

Table 5 Results of Kruskal-Wallis test on community's social capital

\begin{tabular}{llcc}
\hline Kruskal-Wallis test & \multicolumn{1}{c}{ Trust } & Norms & Networking \\
& & & \\
\hline K (Observed value) & 7.1890 & 26.2752 & 30.2063 \\
K (Critical value) & 7.8147 & 7.8147 & 7.8147 \\
DF & 3 & 3 & 3 \\
p-value (Two -tailed) & 0.0661 & $<0.0001$ & $<0.0001$ \\
alpha & 0.05 & 0.05 & 0.05 \\
\hline
\end{tabular}

of unwritten rules, written rules, religious rules, honesty norms, norms of decency, harmonious relations, and norms in land/forest utilization. The result of Kruskal-Wallis test of the seven indicators (Table 5) shows that there was a significant difference of norm variable in the four villages ( $\mathrm{p}$ value smaller than $\alpha 0.05$ ). A further test using multiple pairwise comparisons Dunn's shows that Cilampuyang Village has the lowest average value of norms variable, while Cisitu Village get the highest value (Table 7). Villagers of Cilampuyang and Ganjaresik were not significantly different in terms of understanding the norm as a whole but they differ significantly from the other two villages. The most significant difference indicator in understanding the norms between Cilampuyang Village residents and other village residents was understanding of written rules. This condition indicates that unwritten rules are better understood by Cilampuyang Village community than that of written rules. This implies that unwritten norm is more effectively applied in daily life. The unwritten rules further increase control of the community and give space to the community to remind each other in complying with the norm.

The norms in the utilization of land and forests in the communities in the four villages were almost identical with the protection of water sources, which is among others done by planting wood, especially species that are considered to be able to bring water such as banyan (Ficus benjamina), bunut (Ficus glabela), kiara (Ficus sp), kihujan (Albizia saman), and bamboo. The management of sloping land was done by growing hardwood (timber), bamboo, and long term crops to avoid landslides. Treatment for sloping land was done by making terraces and hoeing in the opposite direction of the slope of the land.
Table 6 Multiple pairwise comparisons using Dunn's procedure/two-tailed test for "trust"

\begin{tabular}{lccccc}
\hline Sample & Frequency & Sum of ranks & $\begin{array}{c}\text { Mean of } \\
\text { ranks }\end{array}$ & \multicolumn{2}{c}{ Groups $^{*}$} \\
\hline Cilampuyang & 33 & 1835.5000 & 55.6212 & A & \\
Ganjaresik & 35 & 2344.5000 & 66.9857 & A & B \\
Cilengkrang & 36 & 2483.5000 & 68.9861 & A & B \\
Cisitu & 31 & 2516.5000 & 81.1774 & & B \\
\hline
\end{tabular}

note: Letter A and B are a symbol for group which is the village having thesame letter has the same group

Networking Networking variables and civic engagement were assessed from 11 indicators i.e. diversity of ethnic in organization membership, diversity of age, diversity of education level, member participation in a group, willingness to establish networking voluntary, cooperation among groups within the community, cooperation with groups outside the community, organizational togetherness, collaboration in solving collective problems, level of personal participation in the group, and number of organizations followed. Overall, there were significant differences between the four villages in terms of network variables as presented in Table 5. This can be seen from the result of Kruskal-Wallis analysis where p-value value $<0.0001$ is less than $\alpha=0.05$ (95\% significance level).

The multiple pairwise comparisons Dunn test shows that there was no apparent difference in networking variables among villagers in Cilengkrang, Ganjaresik, and Cisitu villages (Table 8). Likewise, for Cilampuyang and Cisitu villages, there is no significant difference. The significant difference occured between villagers from Cilampuyang with the other two villages (Cilengkrang and Ganjaresik). Differences occur in indicators of cooperation with groups outside the community, where Cilampuyang Village has a higher indicator value. Related to indicator of cooperation with groups outside the community, the leadership and networking capabilities of the group leader plays a very important role.

Considering the good performance of small scale forests supported by high social capital, it is a good chance for implementing PES scheme in the area. PES can be one of the policy options applied so that small-scale forest owners are willing to preserve their forests. PES can also be provided to 
Table 7 Multiple pairwise comparisons using Dunn's procedure/two-tailed test for "norms"

\begin{tabular}{lcllllll}
\hline Sample & Frequency & $\begin{array}{l}\text { Sum } \\
\text { of ranks }\end{array}$ & $\begin{array}{l}\text { Mean } \\
\text { of ranks }\end{array}$ & Groups* \\
\hline Cilampuyang & 33 & 1540.5000 & 46.6818 & A & & \\
Ganjaresik & 35 & 2048.5000 & 58.5286 & A & B & C \\
Cilengkrang & 36 & 2876.0000 & 79.8889 & & B & C \\
Cisitu & 31 & 2715.0000 & 87.5806 & & & C \\
\hline
\end{tabular}

note: Letter A, B, and C are a symbol for group which is the village having the same letter has the same group
Table 8 Multiple pairwise comparisons using Dunn's procedure/two-tailed test for "networking"

\begin{tabular}{llllll}
\hline Sample & Frequency & $\begin{array}{l}\text { Sum of } \\
\text { ranks }\end{array}$ & $\begin{array}{l}\text { Mean of } \\
\text { ranks }\end{array}$ & Groups* \\
\hline Cilengkrang & 36 & 1808.5000 & 50.2361 & $\mathrm{~A}$ & \\
Ganjaresik & 35 & 1932.0000 & 55.2000 & $\mathrm{~A}$ & \\
Cisitu & 31 & 2238.0000 & 72.1935 & $\mathrm{~A}$ & $\mathrm{~B}$ \\
Cilampuyang & 33 & 3201.5000 & 97.0152 & & $\mathrm{~B}$ \\
\hline
\end{tabular}

note: Letter A and B are a symbol for group which is the village having the same letter has the same group

Table 9 Community response if there are PES incentives for small-scale private forests

\begin{tabular}{lccccc}
\hline Village & $\begin{array}{l}\text { Number of } \\
\text { respondents }\end{array}$ & $\begin{array}{l}\text { Sum of small- } \\
\text { scale forest } \\
\text { owner }\end{array}$ & $\begin{array}{l}\text { Preserve small- } \\
\text { scale forests }\end{array}$ & $\begin{array}{l}\text { If there is an } \\
\text { incentive, thesmall- } \\
\text { scale forestswill be } \\
\text { preserved }\end{array}$ & $\begin{array}{l}\text { Sum of } \\
\text { cropland } \\
\text { owner }\end{array}$ \\
\hline Cilengkrang & 36 & 27 & $\begin{array}{l}\text { If there is an incentive, the } \\
\text { cropland will be converted to } \\
\text { small-scale forests }\end{array}$ \\
Ganjaresik & 35 & 23 & 27 & 27 & 23 \\
Cisitu & 31 & 31 & 29 & 31 & 21 \\
Cilampuyang & 33 & 31 & 28 & 31 & 4 \\
\hline Sum & 135 & 112 & 105 & 112 & 3 \\
\hline
\end{tabular}

potential landowners to manage their land into small-scale forests. Environmental service incentives are offered to landowners whose decisions may be affected by economic rationality and other factors (van der Horst 2011).

The effectiveness of the PES scheme, when it is implemented, can be predicted from the community response to the PES incentive offered for small-scale forests and incentives for agricultural land to be converted to small-scale forests (Table 9). PES incentives will effectively preserve existing forests and avoid any change in management. Six percent of small-scale forest owners will change their landuse management into cropland management if there is no incentive offered. In addition, PES incentive offered will also change the form of cropland management into woodland or agroforestry which is owned by $26 \%$ of respondents.

Some reasons mentioned by respondents of why incentives would prevent the rate of change of small-scale forest that were: (1) everyone needs wood, (2) small-scale forests have environmental benefits to prevent drought, erosion and landslides, and (3) small scale forest saves a lot of farming cost, and assure the fulfillment of daily needs. On the other hand, respondents willing to convert agricultural land into small-scale forest due to several resasons: (1) te land is located far from settlement and limited time availability, (2) many pests (monkeys) if the land is cultivated for crops, (3) provision of incentives, and (4) if not all the land is planted with forest trees. The results of this study confirm findings from Urquhart et al. (2012), who argued that landowners have different motivations and attitudes in managing their forests for the benefit of public service providers such as environmental services.
Through PES schemes, multilayer benefits of small scale forestry will not only be accepted by local communities but it can also provide benefits on a wider scale for more beneficiaries. On a larger scale, small-scale forests can significantly affect the control of annual water yields in watersheds. In order to increase the utilization of environmental benefits of forests on a wider scale, the potential of existing social capital should be encouraged to be a collective action to conserve existing forests while encouraging the development of more small-scale forests. According to Prisma (2003), social capital is an important element in landscape arrangement and the provision of environmental services.

The design of payment for environmental services The design of payment for environmental services on the smallscale private forest in water catchment areas of Jatigede reservoir can be designed with reference to the PES scheme of The Regional Forum on Payment Schemes for Environmental Services in Watersheds covering context, actors, valuation financing and costs, operation and design, and monitoring (Parlinah 2018). It is further explained that the design of PES schemes that can be applied to small-scale forest in the catchment area of Jatigede Reservoir is:

1 PES context is intended to (1) maintain the quality and quantity of water in the catchments of Jatigede Reservoir, (2) additional sources of income for smallholder forest farmers, and (3) incentives in respect of maintaining the existence of the small-scale forests.

2 Actors: The owner of small-scale forests is a provider of watershed protection services, while the buyers of 
Table 10 A review of suitability of community institution (farmers group) based on design principles institution by Ostrom (1990) to support the development of PES

\begin{tabular}{|c|c|c|c|c|}
\hline Principle & $\begin{array}{l}\text { Cimedang Farmers } \\
\text { Group (Cilengkrang } \\
\text { Village) }\end{array}$ & $\begin{array}{l}\text { Temu Hurip Farmers Group } \\
\text { (Ganjaresik Village) }\end{array}$ & $\begin{array}{l}\text { Mekar Mandiri Farmers } \\
\text { Group (Cisitu Village) }\end{array}$ & $\begin{array}{l}\text { Malar Wangi Group } \\
\text { (Cilampuyang Village) }\end{array}$ \\
\hline $\begin{array}{l}\text { Collective choice } \\
\text { arrangements }\end{array}$ & $\begin{array}{l}\text { YES: Policy } \\
\text { arrangements are made } \\
\text { by deliberation }\end{array}$ & $\begin{array}{l}\text { YES: Policy arrangements are } \\
\text { made by deliberation }\end{array}$ & $\begin{array}{l}\text { YES: Policy arrangements } \\
\text { are made by deliberation }\end{array}$ & $\begin{array}{l}\text { YES: Policy arrangements } \\
\text { are made by deliberation }\end{array}$ \\
\hline Monitoring & $\begin{array}{l}\text { YES: Monitoring } \\
\text { conducted by aid } \\
\text { providers }\end{array}$ & $\begin{array}{l}\text { YES: Monitoring conducted by } \\
\text { aid providers and member's } \\
\text { annual meetings }\end{array}$ & $\begin{array}{l}\text { YES: Monitoring } \\
\text { conducted by aid providers } \\
\text { and member's annual } \\
\text { meetings }\end{array}$ & $\begin{array}{l}\text { YES: Monitoring conducted } \\
\text { by aid providers and } \\
\text { member's annual meetings }\end{array}$ \\
\hline Graduated sanction & $\begin{array}{l}\text { YES: Members shall } \\
\text { be subject to the rules } \\
\text { of the farmer group }\end{array}$ & $\begin{array}{l}\text { YES: Members shall be subject } \\
\text { to the rules of the farmer group }\end{array}$ & $\begin{array}{l}\text { YES: Members shall be } \\
\text { subject to the rules of the } \\
\text { farmer group }\end{array}$ & $\begin{array}{l}\text { YES: Members shall be } \\
\text { subject to the rules of the } \\
\text { farmer group }\end{array}$ \\
\hline $\begin{array}{l}\text { Conflict resolution } \\
\text { mechanisms }\end{array}$ & $\begin{array}{l}\text { YES: Consensus } \\
\text { decision mechanism }\end{array}$ & $\begin{array}{l}\text { YES: Consensus decision } \\
\text { mechanism }\end{array}$ & $\begin{array}{l}\text { YES: Consensus decision } \\
\text { mechanism }\end{array}$ & $\begin{array}{l}\text { YES: Consensus decision } \\
\text { mechanism }\end{array}$ \\
\hline $\begin{array}{l}\text { Minimal recognition of rights } \\
\text { to organize }\end{array}$ & $\begin{array}{l}\text { LESS: There is no } \\
\text { official decision from } \\
\text { the Ministry of Justice } \\
\text { and Human Rights }\end{array}$ & $\begin{array}{l}\text { YES: The farmer group is } \\
\text { legalized through the Decree of } \\
\text { Ganjaresik Village Head and } \\
\text { Decree of the Minister of Law } \\
\text { and Human Rights of the } \\
\text { Republic of Indonesia }\end{array}$ & $\begin{array}{l}\text { YES: The farmer group is } \\
\text { legalized through the } \\
\text { Decree of Cisitu Village } \\
\text { Head and Decree of the } \\
\text { Minister of Law and } \\
\text { Human Rights of the } \\
\text { Republic of Indonesia } \\
\text { group }\end{array}$ & $\begin{array}{l}\text { YES: The farmer group is } \\
\text { legalized through the Decree } \\
\text { of the Minister of Law } \\
\text { and Human Rights of } \\
\text { the Republic of Indonesia }\end{array}$ \\
\hline Nested enterprises & $\begin{array}{l}\text { YES: The core } \\
\text { manager is a member } \\
\text { of the farmer group }\end{array}$ & $\begin{array}{l}\text { YES: The core manager is a } \\
\text { member of the farmer group }\end{array}$ & $\begin{array}{l}\text { YES: The core manager is } \\
\text { a member of the farmer }\end{array}$ & $\begin{array}{l}\text { YES: The core manager is a } \\
\text { member of the farmer group }\end{array}$ \\
\hline
\end{tabular}

environmental services are water users, among others, users of water supply company, irrigation users and Jatigede Reservoir authority. A non-structural institution of environmental services to be established based on West Java Provincial Regulation Numbered 5 Year 2015 can be a facilitator in the implementation of environmental services. Existing community institutions can be empowered for managing the funds received from buyers. The extension agents or third parties such as nongovernmental organizations can be assistant in implementing the PES mechanism

3 Valuation financing and costs: Payment mechanisms can be set forth in the form of cooperation agreements between environmental service providers and buyers of environmental services (service beneficiaries). The results of environmental services valuation can be used as a reference for both parties in negotiating. One approach that can be used is through the calculation of willingness to pay (WTP) of water company users. For example, the WTP of Tirta Medal Company users, company utilizing the Cimanuk river water, is IDR2,366,124 month $^{-1}$ or IDR28,393,488 year ${ }^{-1}$

4 Operation and design: The type of environmental services is to maintain the quality and quantity of water through watershed protection. To maintain the quality and quantity of water can be done by (1) maintaining the existing small-scale private forests and (2) change the management of agricultural crops cultivation into agroforestry management. Incentives can be in form of cash money or activities related to the 
maintenance/development of small-scale forests, and economic empowerment activities to provide alternative sources of income.

5 Monitoring and evaluation of PES implementation can be done by non-structural institution.

Social capital and community institution to support the development of payment for environmental services Local norms and the existence of local leaders in the community are factors that can be harnessed for the success of the self-organized institution of the resource regime (Ostrom 2000). Local norms in land/forest utilization such as in hardwood planting around the springs and on land having high slopes, common knowledge about the environmental benefits of small scale forests and the existence of local leaders (religious leaders) trusted by the community, can serve as a bridge for the creation of collective action in the implementation of payment for environmental services scheme. Suharti et al. (2016) stated that to achieve collective action, social capital should be activated through the intervention of symbolic power inherent in role models.

Collective action of the community has been reflected from the existence of community institutions of farmers (farmer groups) which is capable in facilitating collective actions such as facilitation and implementation for programs related to agriculture, forestry and livestock activities. Example of community institution existing in each village are Cimedang Farmer Group (Cilengkrang Village), Temu Hurip Farmer Group (Ganjaresik Village), Mekar Mandiri Farmer Group (Cisitu Village), and Malar Wangi Farmer Group (Cilampuyang Village). The number of group members was about 40 people, with its membership being voluntary. Generally, group members live within the same territory or have arable land within the same territory. Land ownership of group members is private property, so the boundaries of the territory are clearly defined.

Mutual trust among the people, high trust in religious leaders (local leaders) and mutual cooperation to assist various community activities are a characteristic of the community in the study sites. Participation in activities not only in the form of labor but also in the form of goods for example wood to build places of worship. This is typical of communities having "bonding" social capital membership of farmer groups varies from age and education level (elementary to senior high school). Viewed from the frequency of group meetings, there were some variations. Cimedang Farmer Group and Mekar Mandiri Farmer Group had meetings in accordance with the needs of the activities to be carried out. Whereas Temu Hurip Farmer Group and Malar Wangi Farmer Group organized regular meetings once in a month and have other meetings when needed. The participation level of the member groups was high.

Participation is one of the important dimensions that will affect the implementation of PES (Adhikari \& Boag 2013). Active participation of communities in the development of project concepts, ecosystem infrastructure, and PES management frameworks plays an important role in the success of the PES scheme in Caura (Trinidad) (Rawlins \& Westby 2013). Furthermore, Adhikari and Boag (2013) found that the ability to participate in PES scheme can be influenced by household socio-economic characteristics, ownership structure, social dynamics, and strength of community relations and local institutional management.

Group policy arrangements at all farmer group in the research site (Cimedang, Temu Hurip, Mekar Mandiri, and Malar Wangi) are conducted through deliberation and active participation of group members. All members have the same voting rights. One form of collective choice is when the farmer groups get aid from the government then a deliberation is held to determine the distribution of aid and the way it works. If within the farmer's group working area there is land belonging to the members from other farmer groups, then the allocation of assistance such as seeds for the relevant land would be granted according to collective decision of the group members.

Next, effectiveness possibility of the community institutions (farmers' groups) in managing the community forest resources is assessed based on the institutional design principles of Ostrom (1990), which include clearly defined boundaries, congruence between appropriation and provision rules and local condition, collective choice arrangements, monitoring, graduated sanction, conflict resolution mechanisms, minimal recognition of rights to organize, and nested enterprises (Table 10). Result from the research reveals that three farmer groups (Temu Hurip, Mekar Mandiri, and Malar Wangi) were qualified as community institutions for managing resources for PES scheme effectively, but not for Cimedang Farmer Groups which only meet 7 principles and could not meet one principle i.e. recognition of the right to organize. From the research, it is found that this farmer group has not yet had a formal legal decision letter as a legal basis to regulate various activities. Therefore, it is necessary for Cimedang Farmer Groups can immediately have legal entity as legal basis to organize various activities.

The involvement of community institutions in the implementation of PES schemes is necessary to ensure that the environmental services payment scheme can be effective and have long-term prospects. Rosa et al. (2004) stated that social organization is required negotiate successfully with intermediaries and external agents, and needed to deal with internal distribution issues and other conflicts. Research conducted by Clements et al. (2010) showed that PES initiatives in Cambodia with an approach relying on local institutions were initially ineffective compared to direct payments to individuals, although it was gradually strengthened and had stronger longer-term prospects.

\section{Conclusion}

Identification of potential social capital (trust, norm, network and civic engagement) is an important step to know the potential of collective action in resource management. The results of the study indicate that level of public trust to community local leaders is very high. This role model can be an entry point in introducing the payment for environmental services mechanism as well as initiating its action. There is common knowledge prevailing in the community that small scale forests are environmentally beneficial and societal norms related to the protection of springs can be the source of support for developing PES policies. Leadership and networking capability of group leader becomes an 
opportunity as bridging social capital of the community to cooperate in realizing PES policy. The farmer group as one of the community institutions is a reflection of the potential of collective action where the farmer group can be empowered and strengthened to support the implementation of PES incentives. Meanwhile, for the development of payment for environmental services in communities with relatively low social capital, active support from support organizations such as NGOs is required. The agency plays an important role in providing technical, operational, and mediation assistance to other agencies or markets.

\section{Acknowledgements}

The authors would like to express sincere gratitude to Indonesia's Ministry of Environment and Forestry for providing funding for the study.

\section{References}

Acquaah M, Amoako-Gyampah K, Nyathi NQ. 2014. Measuring and Valuing Social Capital: A Systematic Review. South Africa: Network for Business Sustainability South Africa. nbs.net/knowledge. [15 February 2016].

Adhikari B, Boag G. 2013. Designing payments for ecosystem services schemes: Some considerations. Current Opinion on Environmental Sustainability 5:72-77. https://doi.org/10.1016/j.cosust.2012.11.001.

Ajayi O, Jack BK, Leimona B. 2012. Auction design for the private provision of public goods in developing countries: Lessons from payments for environmental services in Malawi and Indonesia. World Development 40(6):12213-12223. https://doi.org/10.1016/j. worlddev.2011.12.007.

Agnitsch K, FloraJ, Ryan V. 2006. Bonding and bridging social capital: The interactive effects on community action. Community Development. Journal of the Community Development Society 37(1):36-51. https://doi.org/10.1080/15575330609490153.

Badan Pusat Statistik Kabupaten Garut. 2016. Kecamatan Malangbong dalam Angka 2016. Garut: BPS Kabupaten Garut.

Badan Pusat Statistik Kabupaten Sumedaang. 2016. Kecamatan Wado dalam Angka 2016. Sumedang: BPS Kabupaten Sumedang.

Beckmann V, Padmanabhan M, editor. 2009. Institutional and Sustainability. Springer. https://doi.org/10.1007/ 978-1-4020-9690-7.

Clements T, John A, Nielsen K, An, D, Tan S, Gulland EJM. 2010. Payment for biodiversity conservation in the context of weak institutions: Comparison of three programs from Cambodia. Ecological Economics 69:1283-1291. https://doi.org/10.1016/j.ecolecon. 2009.11 .010 .
Darusman D, Hardjanto. 2006. Tinjauan ekonomi hutan rakyat. Kontribusi Hutan Rakyat dalam Kesinambungan Industri Kehutanan. In: Prosiding Seminar Hasil Penelitian Hasil Hutan; Bogor, 21 September 2006. Pp: 4-13.

Djohan R. 2008. Leaders and Social Capital: Lead to Togetherness. Jakarta: Fund Asia Education.

Emerton L. 1999. Community-Based Incentives for Nature Conservation. IUCN-The World Conservation Union-Eastern Africa Regional Office and Economics Unit. http://economics.iucn.org. [18 October 2012].

Engel S, Pagiola S, Wunder S. 2008. Designing payment for environmental services in theory and practice: An overview of the issues. Ecological Economics 65:663-674. https://doi.org/10.1016/j.ecolecon.2008. 03.011 .

Fukuyama F. 2007. Trust: Kebijakan Sosial dan Penciptaan Kemakmuran. Second Edition. Translated from: Trust: The Social Virtues and the Creation of Prosperity. Ruslani, translator. Jakarta: Penerbit Qalam.

Hardjanto. 2001. Kontribusi hutan rakyat terhadap pendapatan rumah tangga di sub DAS Cimanuk Hulu. Jurnal Manajemen Hutan Tropika VII(2):47-61.

Junaidi E, Tarigan SD. 2011. Pengaruh hutan dalam pengaturan tata air dan proses sedimentasi daerah aliran sungai (DAS): Studi kasus di DAS Cisdane. Jurnal Penelitian Hutan dan Konservasi Alam 8(2):155-176. https://doi.org/10.20886/jphka.2011.8.2.155-176.

Kerr J, Milne G, Chhotray V, Baumann P, James AJ. 2007. Managing watershed externalities in India: Theory and practice. Environment, Development, and Sustainability 9:263-281. https://doi.org/10.1007/ s10668-005-9022-3.

Kibena J, Nhapi I, Gumindoga W. 2014. Assessing the relationship between water quality parameters and changes in landuse patterns in the Upper Manyame River, Zimbabwe. Physics and Chemistry of the Earth 67-69: 153-163. https://doi.org/10.1016/j.pce.2013. 09.017

Kosoy N, Tuna MM, Muradian R, Alier JM. 2007. Payments for environmental services in watersheds: Insights from a comparative study of three cases in Central America. Ecological Economics 6:446-455. https://doi.org/10.1016/j.ecolecon.2006.03.016.

Lastini T. 2012. Tipologi desa hutan rakyat: kasus di Kabupaten Ciamis [disertasi]. Bogor: Institut Pertanian Bogor.

Liu J, Qu H, Huang D, Chen G, Yue X, Zhao X, Liang Z. 2014. The role of social capital in encouraging residents' pro-environmental behaviors in communitybased ecotourism. Tourism Management 41:190-201. 
https://doi.org/10.1016/j.tourman.2013.08.016.

Mauthe MB, Oleson KLL, Brander LM, Zafindrasilivonona B, Oliver TA, Van Beukering P. 2015. Social capital as an ecosystem service: Evidence from a locally managed marine area. Ecosystem Services 16:283-293. https://doi.org/10.1016/j.ecoser.2014.10.009.

Muradian R, Corbera E, Pascual U, Kosoy N, May PH. 2010. Reconciling theory and practice: An alternative conceptual framework for understanding payments for environmental services. Ecological Economics 69:1202-1208. https://doi.org/10.1016/j.ecolecon. 2009.11.006.

Nugroho B, Tiryana T. 2013. Implication of the private property right to the community forest businesses formalization through the certification policy. Jurnal Manajemen Hutan Tropika. XIX(3):178-186. https://doi.org/10.7226/jtfm.19.3.178.

Ostrom E. 1990. Governing the Commons: The Evolution of Institutions for Collective Action. United States of America: Cambridge Unniversity Press. https://doi.org/10.1017/CBO9780511807763.

Ostrom E. 2000. Collective action and the evolution of social norms. The Journal of Economic Prospective. 14(3):137-158.

[Prisma] Programa Salvadoreño de Investigación Sobre Desarrollo y Medio Ambiente. 2003. Compensation for Environmental Services and Rural Communities: Lessons from the Americas and Key Issues for Strengthening Community Strategies. Miami (USA). Prisma.

Parlinah N. 2018. Model pengembangan pembayaran jasa lingkungan hutan rakyat di daerah tangkapan air Waduk Jatigede [disertasi]. Bogor: Institut Pertanian Bogor.

Putnam RD, Leonardi R, Nonetti RY. 1993. Making Democracy Work: Civic Traditions in Modern Italy. Princeton, New Jersey: Princeton University Press. https://doi.org/10.1145/358916.361990.

Putnam RD. 2000. Bowling Alone: The Collapse and Revival of American Community. New York: Simon and Schuster.

Rawlins MA, Westby L. 2013. Community participation in payment for ecosystem services design and implementation: an example from Trinidad. Ecosystem Services 6:117-121. https://doi.org/10.1016/j.ecoser. 2013.09.004.

Rosa H, Barry D, Kandel S, Dimas L. 2004. Compensation for Environmental Services and Rural Communities. Lessons from the Americas. Amherst: Political Economy Research Institute, University of Massachusetts.
Suharti S, Darusman D, Nugroho B, Sundawati L. 2016. Strengthening social capital for propelling collective action in mangrove management. Wetlands Ecology and Management 24(6):683-695. https://doi.org/10.1007/s11273-016-9496-9.

Supranto J. 2000. Statistik, Teori dan Aplikasi. In: Tulus S, Ali S, editors. 6th edition. Jakarta: Erlangga Press.

The Regional Forum on Payment Schemes for Environmental Services in Watersheds, the Third Latin American Congress on Watershed Management. 2004. Payment Schemes for Environmental Services in Watersheds. Rome: FAO.Urquhart J, Courtney P, Slee B. 2012. Private woodland owner's perspectives on multifunctionality in England woodlands. Journal of Rural Studies 28:95-106. https://doi.org/10.1016/ j.jrurstud.2011.08.006.

van der Horst. 2011. Adoption of payments for ecosystem services: An application of the Hägerstrand model. Applied Geography 31:668-678. https://doi.org/ 10.1016/j.apgeog.2010.12.001.

Widarti A. 2015. Contribution of small scale private forest for environmental and income sustainability. In: Proceeding Seminar Nasional Masyarakat Biodiversitas Indonesia. 1(7): 1622-1626.

Woolcock M. 2001. The place of social capital in understanding social and economic outcomes. The Isuma Canadian Journal of Policy Research 2(1):11-17.

Yin R, Liu T, Yao S, Zhao M. 2013. Designing and implementing payments for ecosystem services programs: lessons learned from China's cropland restoration experience. Forest Policy and Economics 35:66-72. https://doi.org/10.1016/j.forpol.2013.06. 010 .

Susanto DF, Aparamarta HW, Widjaya A, Gunawan S. 2017. Identification of phytochemical compounds in Calophyllum inophyllum leaves. Asian Pacific Journal of Tropical Biomedicine 7(9):773-781. https://doi.org/10.1016/j.apjtb.2017.08.001.

Tsakaldimi M, Tsitsoni T, Ganatsas P, Zagas T. 2009. A comparison of root architecture and shoot morphology between naturally regenerated and container-grown seedlings of Quercus ilex. Plant and Soil 324:103-113. https://doi.org/10.1007/s11104-009-9974-4.

van Sambeek JW, Godsey LD, Walter WD, Garrett HE, Dwyer JP. 2016. Field performance of Quercus bicolor established as repeatedly air-root-pruned container and bareroot planting stock. Open Journal of Forestry 6:163-176. https://doi.org/10.4236/ojf.2016.63014.

Vandana V, Kodanda RRCH, Somnath G, Babia L. 2017. Synthesis of Calophyllum inophyllum esters as biofuel 
feed stock. JOJ Material Science 2(2):555-583. https://doi.org/10.19080/JOJMS.2017.02.555583.

Vaverkova M, Adamcova D, Kotovicova J, Toman F. 2014. Evaluation of biodegradability of plastics bags in composting conditions. Ecology and Chemical
Engeneering Science 21(1):45-57. https://doi.org/10. 2478/eces-2014-0004.

Zahawi RA, Holl KD. 2009. Comparing the performance of tree stakes and seedlings to restore abandoned tropical pastures. Restoration Ecology 17:854-864. https://doi.org/10.1111/j.1526-100X.2008.00423.x. 